\title{
Publisher Correction: Experimental orthotopic transplantation of a tissue-engineered oesophagus in rats
}

Sebastian Sjöqvist, Philipp Jungebluth, Mei Ling Lim, Johannes C. Haag, Ylva Gustafsson, Greg Lemon, Silvia Baiguera, Miguel Angel Burguillos, Costantino Del Gaudio, Antonio Beltrán Rodríguez, Alexander Sotnichenko, Karolina Kublickiene, Henrik Ullman, Heike Kielstein, Peter Damberg, Alessandra Bianco, Rainer Heuchel, Ying Zhao, Domenico Ribatti, Cristián Ibarra, Bertrand Joseph, Doris A. Taylor \& Paolo Macchiarini

Nature Communications 5:3562 doi: 10.1038/ncomms4562 (2014); Published online 15 Apr 2014; Updated 10 Apr 2018

The original HTML version of this Article had an incorrect article number of 4562; it should have been 3562 . This has now been corrected in the HTML; the PDF version of the Article was correct from the time of publication.

\footnotetext{
(c) Open Access This article is licensed under a Creative Commons Attribution 4.0 International License, which permits use, sharing, adaptation, distribution and reproduction in any medium or format, as long as you give appropriate credit to the original author(s) and the source, provide a link to the Creative Commons license, and indicate if changes were made. The images or other third party material in this article are included in the article's Creative Commons license, unless indicated otherwise in a credit line to the material. If material is not included in the article's Creative Commons license and your intended use is not permitted by statutory regulation or exceeds the permitted use, you will need to obtain permission directly from the copyright holder. To view a copy of this license, visit http://creativecommons.org/licenses/by/4.0/
}

(C) The Author(s) 2018 